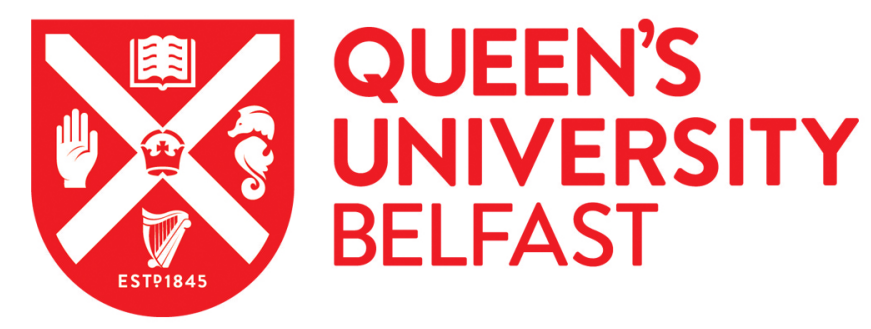

\title{
Quantitative analysis of the reactivity of formate species seen by DRIFTS over a Au/Ce(La)O2 water-gas shift catalyst: First unambiguous evidence of the minority role of formates as reaction intermediates
}

Meunier, F., Reid, D., Goguet, A., Shekhtman, S., Hardacre, C., Burch, R., Deng, W., \& Flytzani-

Stephanopoulos, M. (2007). Quantitative analysis of the reactivity of formate species seen by DRIFTS over a $\mathrm{Au} / \mathrm{Ce}(\mathrm{La}) \mathrm{O} 2$ water-gas shift catalyst: First unambiguous evidence of the minority role of formates as reaction intermediates. Journal of Catalysis, 247(2)(2), 277-287. https://doi.org/10.1016/j.jcat.2007.02.013

Published in:

Journal of Catalysis

Queen's University Belfast - Research Portal:

Link to publication record in Queen's University Belfast Research Portal

\section{General rights}

Copyright for the publications made accessible via the Queen's University Belfast Research Portal is retained by the author(s) and / or other copyright owners and it is a condition of accessing these publications that users recognise and abide by the legal requirements associated with these rights.

Take down policy

The Research Portal is Queen's institutional repository that provides access to Queen's research output. Every effort has been made to ensure that content in the Research Portal does not infringe any person's rights, or applicable UK laws. If you discover content in the Research Portal that you believe breaches copyright or violates any law, please contact openaccess@qub.ac.uk. 


\title{
Quantitative analysis of the reactivity of formate species seen by DRIFTS over a $\mathrm{Au} / \mathrm{Ce}(\mathrm{La}) \mathrm{O}_{2}$ water-gas shift catalyst: First unambiguous evidence of the minority role of formates as reaction intermediates
}

\author{
F.C. Meunier ${ }^{\mathrm{a}, *}$, D. Reid ${ }^{\mathrm{a}}$, A. Goguet ${ }^{\mathrm{a}}$, S. Shekhtman ${ }^{\mathrm{a}}$, C. Hardacre ${ }^{\mathrm{a}}$, R. Burch ${ }^{\mathrm{a}}$, W. Deng ${ }^{\mathrm{b}}$, \\ M. Flytzani-Stephanopoulos ${ }^{b}$ \\ ${ }^{a}$ CenTACat, School of Chemistry and Chemical Engineering, Queen's University Belfast, Belfast, BT9 5AG, Northern Ireland, UK \\ ${ }^{\mathrm{b}}$ Department of Chemical and Biological Engineering, Tufts University, Medford, MA 02155, USA
}

Received 24 January 2007; revised 13 February 2007; accepted 13 February 2007

Available online 21 March 2007

\begin{abstract}
The reactivity of the species formed at the surface of a $\mathrm{Au} / \mathrm{Ce}(\mathrm{La}) \mathrm{O}_{2}$ catalyst during the water-gas shift (WGS) reaction were investigated by operando diffuse reflectance Fourier transform spectroscopy (DRIFTS) at the chemical steady state during isotopic transient kinetic analyses (SSITKA). The exchanges of the reaction product $\mathrm{CO}_{2}$ and of formate and carbonate surface species were followed during an isotopic exchange of the reactant CO using a DRIFTS cell as a single reactor. The DRIFTS cell was a modified commercial cell that yielded identical reaction rates to that measured over a quartz plug-flow reactor. The DRIFTS signal was used to quantify the relative concentrations of the surface species and $\mathrm{CO}_{2}$. The analysis of the formate exchange curves between 428 and $493 \mathrm{~K}$ showed that at least two levels of reactivity were present. "Slow formates" displayed an exchange rate constant 10 - to 20 -fold slower than that of the reaction product $\mathrm{CO}_{2}$. "Fast formates" were exchanged on a time scale similar to that of $\mathrm{CO}_{2}$. Multiple nonreactive readsorption of $\mathrm{CO}_{2}$ took place, accounting for the kinetics of the exchange of $\mathrm{CO}_{2}(\mathrm{~g})$ and making it impossible to determine the number of active sites through the SSITKA technique. The concentration (in mol g${ }^{-1}$ ) of formates on the catalyst was determined through a calibration curve and allowed calculation of the specific rate of formate decomposition. The rate of $\mathrm{CO}_{2}$ formation was more than an order of magnitude higher than the rate of decomposition of formates (slow + fast species), indicating that all of the formates detected by DRIFTS could not be the main reaction intermediates in the production of $\mathrm{CO}_{2}$. This work stresses the importance of full quantitative analyses (measuring both rate constants and adsorbate concentrations) when investigating the role of adsorbates as potential reaction intermediates, and illustrates how even reactive species seen by DRIFTS may be unimportant in the overall reaction scheme.
\end{abstract}

(c) 2007 Elsevier Inc. All rights reserved.

Keywords: Operando; In situ; SSITKA; DRIFT; FTIR; Spectroscopy; Water-gas shift; Formate; Carbonate; Surface species; Gold; Ceria; Spectator; Reaction mechanism

\section{Introduction}

Ceria-supported noble metal-based materials are currently receiving much interest as promising oxidation-resistant and durable low-temperature water-gas shift (WGS; $\mathrm{CO}+\mathrm{H}_{2} \mathrm{O} \rightarrow$ $\mathrm{CO}_{2}+\mathrm{H}_{2}$ ) catalysts [1-12]. The role of formates as potential reaction intermediates has been much discussed, often as an alternative route to a redox mechanism [13-20]. Burch re-

\footnotetext{
* Corresponding author. Fax: +442890974890.

E-mail address: f.meunier@qub.ac.uk (F.C. Meunier).
}

cently reviewed the field of WGS over Au-based catalysts and proposed a unified WGS mechanism in which the redox route would derive from other routes at the higher temperatures, at which adsorbate surface coverage becomes low [21]. An important feature of this model is the recognition that the dominant mechanism will be a function of the choice of catalyst and the experimental conditions.

Following earlier work by Shido and Iwasawa [3,22], Jacobs et al. [23-27] proposed that the formates generated by the reaction of $\mathrm{CO}$ with bridging $\mathrm{OH}$ groups associated with the $\mathrm{Ce}^{3+}$ defects were main reaction intermediates. The formates were 
thought to decompose to $\mathrm{CO}_{2}(\mathrm{~g})$ via surface carbonate species. Kinetic isotope effect and isotopic tracer studies suggested that the rate-limiting step of the forward formate decomposition was the $\mathrm{C}-\mathrm{H}$ bond rupture, aided by the noble metal [25]. Behm et al. [28] carried out a quantitative analysis of the rate of formate surface decomposition over a $\mathrm{Au} / \mathrm{CeO}_{2}$ catalyst and proposed that formates could account for about half of the $\mathrm{CO}_{2}$ produced. This calculation was based on the nonsteady-state measurement of the rate constant of formate decomposition (i.e., during desorption under $2 \% \mathrm{H}_{2} \mathrm{O}$ in $\mathrm{N}_{2}$ ) and an estimate of the formate surface coverage determined via TPD under $\mathrm{N}_{2}$ of a catalyst pretreated under WGS conditions. Meunier et al. [29] recently proposed that formates can potentially be reaction intermediates over $\mathrm{Pt} / \mathrm{CeO}_{2}$ above $473 \mathrm{~K}$, whereas the formate species seen by DRIFTS were merely reaction spectators below this temperature. It is important to stress that in none of the aforementioned studies, including the one carried out by some of us [29], were the formate decomposition rate constant and surface coverage determined simultaneously at the chemical steady state under WGS reaction conditions.

Meunier et al. showed that the reactivity of surface species over $\mathrm{Pt} / \mathrm{CeO}_{2}$ can dramatically depend on the experimental procedure used [30]. Based on DRIFTS analyses combined with the utilization of isotopic tracers, steady-state experiments showed that formates were less reactive than carbonyl and carbonate species under steady-state conditions, whereas the reverse trend was observed during the desorption-type nonsteady-state experiments carried out in an inert purge gas. The operando DRIFTS-SSITKA method used in the present study uses a single catalytic bed, which allows DRIFTS characterization of the surface of the very same catalyst that is responsible for the catalytic activity measured at the cell exit by gas chromatography or mass spectrometry [8]. This methodology is a powerful tool for an in-depth investigation of catalysts under reaction conditions, similar to the method developed earlier for transmission FTIR by Chuang et al. [31,32].

The present paper deals with reactivity in terms of isotopic exchange of the surface species formed over an $\mathrm{Au} / \mathrm{Ce}(\mathrm{La}) \mathrm{O}_{2}$ catalyst under forward WGS conditions (i.e., $2 \% \mathrm{CO}+7 \%$ $\mathrm{H}_{2} \mathrm{O}$ ). The main objective was to investigate the reactivity of the surface formates species observed under reaction conditions. A fully quantitative analysis was carried out to determine both the rate constant of formate decomposition and the surface coverage of formate under steady-state reaction conditions. This methodology allowed us to compare the specific rate of $\mathrm{CO}_{2}$ formation to that of formate decomposition and to conclude that the formates detected by DRIFTS are not important reaction intermediates in $\mathrm{CO}_{2}$ formation.

\section{Experimental}

The catalyst used in this study was a 0.6 at $\% \mathrm{Au}+7.3$ at $\%$ $\mathrm{La} / \mathrm{CeO}_{2}$ (abbreviated 0.6AuCL) prepared by $\mathrm{NaCN}$ leaching of a higher Au-loading parent material [7]. The bulk composition was determined by ICP. The concentration of La near the surface was determined by XPS to be 19.1 at $\%$, much higher than the bulk content of 7.3 at\% La, due to La enrichment of the surface during the calcination step at $673 \mathrm{~K}$. The BET specific surface area was $161 \mathrm{~m}^{2} \mathrm{~g}^{-1}$. The purity of the gases used $\left(\mathrm{H}_{2}, \mathrm{Kr}, \mathrm{CO}\right.$, and $\mathrm{Ar}$, supplied by BOC) was $>99.95 \%$. The ${ }^{13} \mathrm{CO}$ was $99 \%$ pure (supplied by Cambridge Isotope Laboratories Inc.).

The experimental setup consisted of an in situ high-temperature diffuse reflectance IR cell (from Spectra-Tech) fitted with $\mathrm{ZnSe}$ windows. The DRIFTS cell was located in a Bruker Equinox 55 spectrometer, operating at a resolution of $4 \mathrm{~cm}^{-1}$. The reactor crucible was modified to ensure plug-flow conditions throughout the catalyst bed. The interface between the ceramic reactor and the metallic base plate was sealed with some PTFE tape to prevent any sample bypass. The original porous bed to support the sample was replaced by an inert metallic mesh. The reaction rates measured using the cell was equal to that measured in a conventional tubular plug-flow reactor (vide infra). No conversion of reactant was observed when the crucible was heated up to the reaction temperature in the absence of the catalyst. The cell was connected to the feed gas cylinders through low-volume stainless-steel lines. The gas flows were controlled by Aera mass flow controllers, which were regularly calibrated. A 4-way valve was used to allow fast switching between two reaction feeds, when appropriate. High-purity water was introduced using a single saturator, which delivered a constant and accurate level of water. Note that the water delivery was totally unaffected by the valve switching (as determined by MS or GC analyses [29]).

The amount of catalyst used in the DRIFTS reactor was $78 \pm 2 \mathrm{mg}$ (particle diameter $<150 \mu \mathrm{m}$ ). Unless stated otherwise, the material was brought up to reaction temperature under $\mathrm{Ar}$, and then $7 \mathrm{vol} \%$ of water was added to the Ar stream. A reference DRIFTS single scan was recorded after stabilization of the signal. The reaction mixture (typically $2 \% \mathrm{CO}+$ $7 \% \mathrm{H}_{2} \mathrm{O}$ in $\mathrm{Ar}$ ) was subsequently introduced at a total flow rate of $100 \mathrm{ml} \mathrm{min}{ }^{-1}$. The reaction flow was going down the reactor bed; therefore, the upper layer of the catalyst (which is probed by the DRIFTS technique) was the front of the bed.

Steady-state conditions in terms of the concentration of the surface species measured by DRIFTS were reached in less than $30 \mathrm{~min}$. The assignment of the IR bands and the integration method are described in Section 3. The IR data are reported as $\log 1 / R$, with $R=I / I_{0}$, where $R$ is the sample reflectance, $I_{0}$ is the intensity measured on the sample after exposure to $7 \%$ water, and $I$ is the intensity measured under reaction condition. The function $\log 1 / R$ (="absorbance") gives a better linear representation of the band intensity against sample surface coverage than that given by the Kubelka-Munk function for strongly absorbing media such as $\mathrm{Pt} / \mathrm{CeO}_{2}$ [33].

The determination of the level of exchange of the surface species during the isotopic switch was carried out using a least squares method based on the linear combination of the initial ${ }^{12} \mathrm{C}$-containing and fully exchanged ${ }^{13} \mathrm{C}$-containing spectra. The $2650-3100 \mathrm{~cm}^{-1}$ region was used for the formates, 2400 $2250 \mathrm{~cm}^{-1}$ was used for $\mathrm{CO}_{2}$, and $750-1000 \mathrm{~cm}^{-1}$ was used for the carbonates (Fig. 4). This method appeared to be accurate and led to an improved signal-to-noise ratio compared with that reported earlier [30]. A solver algorithm based on Microsoft 
Excel was used for the parameter optimization. The ${ }^{12} \mathrm{C}$ and ${ }^{13} \mathrm{C}$ responses were symmetric, so any set of exchange curves could be used to compare the relative rate of exchange.

\section{Results}

\subsection{Sample activity and DRIFTS reactor evaluation}

The WGS activity of the 0.6AuCL was measured between 398 and $473 \mathrm{~K}$ in our modified DRIFTS cell (in Belfast) and compared with that evaluated in a traditional quartz plug-flow reactor (in Medford) using the same feed, that is, $2 \% \mathrm{CO}+$ $7 \% \mathrm{H}_{2} \mathrm{O}$ in $\mathrm{Ar}$ (Fig. 1). Only the rates of $\mathrm{CO}_{2}$ formation for which the $\mathrm{CO}$ conversion was $<15 \%$ (i.e., essentially differential conditions) are reported in Fig. 1. A perfect agreement between the rates measured over the two different reactors was

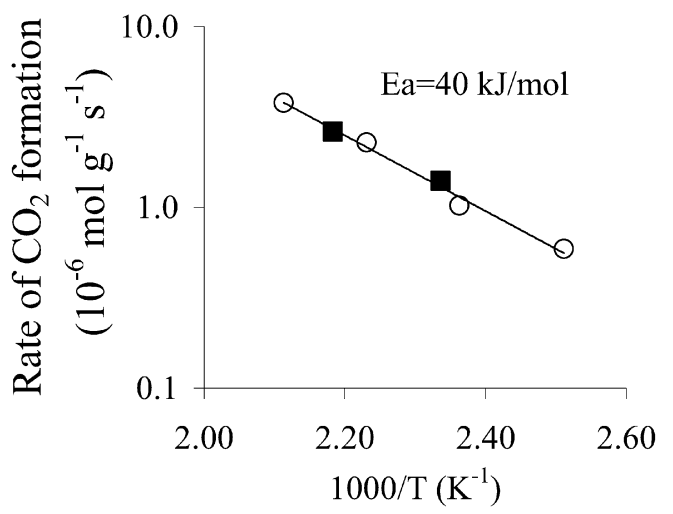

Fig. 1. Arrhenius plot relating to the rate of $\mathrm{CO}_{2}$ formation measured over the $0.6 \mathrm{AuCL}$ sample $(\mathrm{O})$ in a quartz plug-flow reactor in Medford and $(\bullet)$ in the modified DRIFT cell in Belfast. The feed was $2 \%{ }^{12} \mathrm{CO}+7 \% \mathrm{H}_{2} \mathrm{O}$ in $\mathrm{Ar}$ or He. observed. The apparent activation energy of $\mathrm{CO}_{2}$ formation was $40.0 \mathrm{~kJ} \mathrm{~mol}^{-1}$.

\subsection{Nature of the IR spectra and assignment of IR bands}

The in situ DRIFTS spectrum observed over the 0.6AuCL at $493 \mathrm{~K}$ under $7 \% \mathrm{H}_{2} \mathrm{O}$ in $\mathrm{Ar}$ (using a mirror as background) is shown in Fig. 2a. The sample surface was highly hydroxylated, as evidenced by the large band observed in the 3700$2500 \mathrm{~cm}^{-1}$ region, which corresponds to the stretching mode of hydrogen-bonded hydroxyls. The band at $3658 \mathrm{~cm}^{-1}$ is associated with doubly coordinated hydroxyl groups (type II) [34]. The broad band observed in the region between 1800 and $1100 \mathrm{~cm}^{-1}$ indicated the presence of several OCO-containing species, such as carbonates and carboxylates, typically observed over basic solids, such as ceria [35-38]. The presence of carbonate species was clearly evidenced by the $855-\mathrm{cm}^{-1}$ band, assigned to the carbonate out-of-plane bending vibration.

The spectrum of the sample at steady-state conditions at 493 $\mathrm{K}$ under $2 \% \mathrm{CO}+7 \% \mathrm{H}_{2} \mathrm{O}$ in $\mathrm{Ar}$ (using a mirror as background) exhibited some marked modifications (Fig. 2b). New bands at 2946 and $2830 \mathrm{~cm}^{-1}$ were observed, which were associated with the combination band $(\mathrm{C}-\mathrm{H})+v_{\mathrm{s}}(\mathrm{OCO})$ and $v(\mathrm{C}-\mathrm{H})$ of a bidentate formate species, respectively [38]. The additional bands in the $1800-1200 \mathrm{~cm}^{-1}$ region were due in part to the stretching vibration modes (symmetric and asymmetric) of the OCO group of formate and carbonate species. The formates were likely formed by reaction of $\mathrm{CO}$ with the ceria type II hydroxyls, which were no longer observable. Due to the complexity of the band at $1800-1200 \mathrm{~cm}^{-1}$, the deconvolution and interpretation of this region was not attempted. The band observed at $2125 \mathrm{~cm}^{-1}$ is not related to any metalbonded carbonyl groups, because no shift of the band occurs when switching to ${ }^{13} \mathrm{CO}$ (see the next paragraph), but rather to

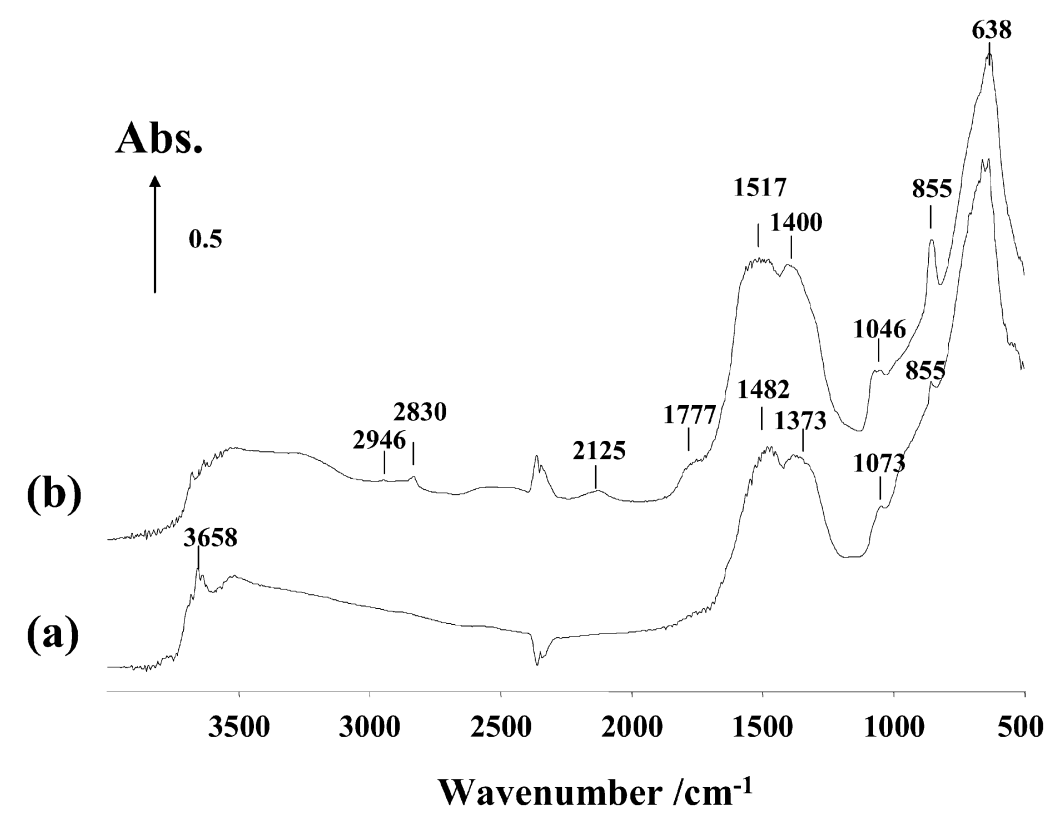

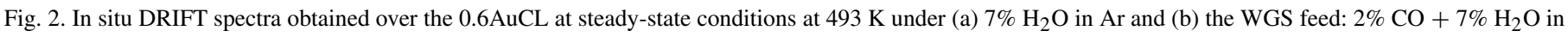
Ar. A mirror signal was used as background. 


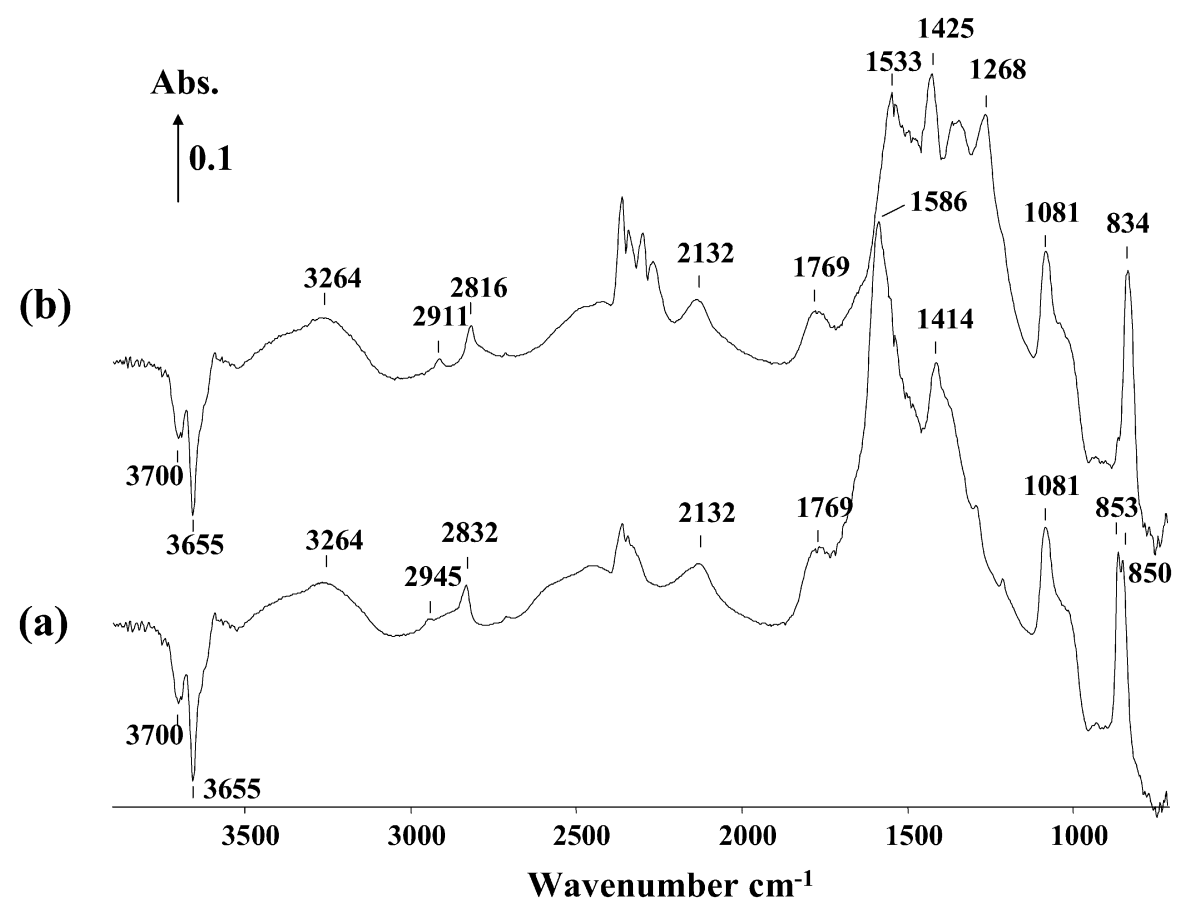

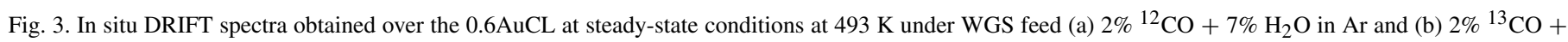
$7 \% \mathrm{H}_{2} \mathrm{O}$ in Ar. The measured $\mathrm{CO}$ conversion was $26 \%$. A spectrum of the same sample under $7 \% \mathrm{H}_{2} \mathrm{O} / \mathrm{Ar}$ at the same temperature was used as background.

a normally forbidden electronic transition of partially reduced ceria [39]. This actually indicates that ceria was partly reduced under our reaction conditions.

The spectrum obtained under WGS conditions (i.e., $493 \mathrm{~K}$ under $2 \% \mathrm{CO}+7 \% \mathrm{H}_{2} \mathrm{O}$ in $\mathrm{Ar}$ ) is also shown using the spectrum of the sample recorded in the presence of water only as background (Fig. 3a). The minor wavenumber differences observed between Figs. $2 \mathrm{~b}$ and $3 \mathrm{a}$ are due simply to the baseline corrections. The formate (2945 and $2832 \mathrm{~cm}^{-1}$ ) and carbonate $\left(853 \mathrm{~cm}^{-1}\right)$ bands were clearly visible. The spectrum obtained 30 min after switching to the corresponding ${ }^{13} \mathrm{C}$-labeled feed (i.e., $2 \%{ }^{13} \mathrm{CO}+7 \% \mathrm{H}_{2} \mathrm{O}$ in $\mathrm{Ar}$ ) is reported in Fig. 3b. Both the formate and carbonate bands shifted to lower wavenumbers, for example, from 2832 to $2816 \mathrm{~cm}^{-1}$ for the formate and from 853 to $834 \mathrm{~cm}^{-1}$ for the carbonates. The isotopic exchange of these surface species was almost completed after $30 \mathrm{~min}$ at this temperature (vide infra). The band at $2132 \mathrm{~cm}^{-1}$ was unchanged when switching to the ${ }^{13} \mathrm{C}$-feed; a red shift of ca. $50 \mathrm{~cm}^{-1}$ would be expected when replacing a ${ }^{12} \mathrm{CO}$ (ads) with ${ }^{13} \mathrm{CO}$ (ads). Such $\mathrm{CO}(\mathrm{ads})$ red shifts are easily observed on Ptbased catalysts [8], which are known to bond $\mathrm{CO}$ even more strongly than Au-based materials do. This observation stresses that the $2132 \mathrm{~cm}^{-1}$ band observed here was not due to any carbonyl species, but simply to an electronic transition occurring over reduced ceria, as discussed by Lavalley et al. [39].

\subsection{Formate, carbonate and $\mathrm{CO}_{2}$ signal exchange over $0.6 A u C L$}

The kinetics of the exchange of the formate and carbonate species and that of the reaction product $\mathrm{CO}_{2}$ were followed using the DRIFTS spectra recorded at three different tempera- tures. The ${ }^{12} \mathrm{CO}_{2}$ and ${ }^{13} \mathrm{CO}_{2}$ relative concentrations were measured using the gas-phase DRIFTS bands at $2400-2250 \mathrm{~cm}^{-1}$ (Fig. 3b). Formate and carbonate exchange curves were determined using the 3100-2700 and 1000-750 regions, respectively (Fig. 4). The data shown in Fig. 4 revealed that the exchange of formates and carbonates over the sample was not fully completed after $30 \mathrm{~min}$ under labeled feed, even at the highest temperature investigated $(493 \mathrm{~K})$, at which it reached $95 \%$. The level of exchange of formates after $30 \mathrm{~min}$ was $73 \%$ at $458 \mathrm{~K}$ and $48 \%$ at $428 \mathrm{~K}$.

Although the exchange of formates and carbonates was only partial after $30 \mathrm{~min}$, the exchange of $\mathrm{CO}_{2}$ was always essentially completed within $20 \mathrm{~min}$ at the three temperatures investigated (see the ${ }^{13} \mathrm{CO}_{2}$ signal in Figs. 5 and 6 for the cases at 428 and $493 \mathrm{~K}$; the data at $458 \mathrm{~K}$ are not shown for the sake of brevity). The curves associated with the $\mathrm{CO}_{2}$ exchange were approximated by a single exponential function (Fig. 7), and the corresponding rate constant Arrhenius plot (Fig. 7, insert) yielded an apparent activation energy of $\mathrm{CO}_{2}$ exchange of $23.7 \mathrm{~kJ} \mathrm{~mol}^{-1}$. It is worth stressing that the apparent activation energy for the formation of $\mathrm{CO}_{2}$ was equal to $40.0 \mathrm{~kJ} \mathrm{~mol}^{-1}$ (see Section 4.1), significantly different from that of the exchange of $\mathrm{CO}_{2}$.

The exchange of the carbonate and formate species appeared to proceed at a similar rate (see the ${ }^{12} \mathrm{C}$-formate and ${ }^{12} \mathrm{C}$ carbonate signals in Figs. 5 and 6). It is obvious from Figs. 5 and 6 that a fraction of the formates and carbonates exchanged on a similar time scale to that of the $\mathrm{CO}_{2}$, whereas the remainder exchanged much more slowly. Accordingly, the curves associated with the exchange of the formate and carbonate signals could not be fitted to a simple exponential plot, as would be expected for a first-order exchange of uniform species. As an 
(a)

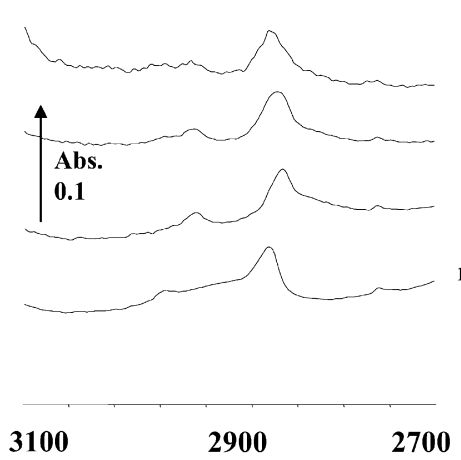

Wavenumber $/ \mathrm{cm}^{-1}$ (b)

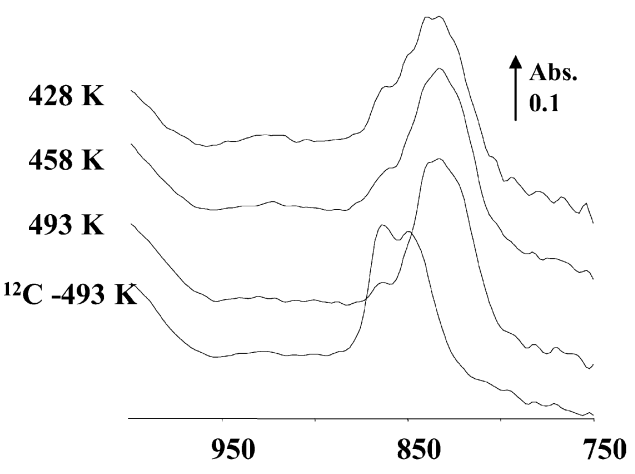

Wavenumber $/ \mathrm{cm}^{-1}$

Fig. 4. Details of the formate and carbonate regions of the in situ DRIFT spectra obtained over of the $0.6 \mathrm{AuCL}$ under $2 \%{ }^{12} \mathrm{CO}+7 \% \mathrm{H}_{2} \mathrm{O}$ in $\mathrm{Ar}$ (bottom spectrum) and 30 min under $2 \%{ }^{13} \mathrm{CO}+7 \% \mathrm{H}_{2} \mathrm{O}$ in $\mathrm{Ar}$ at various temperatures (three top spectra). A spectrum of each same sample under $7 \% \mathrm{H}_{2} \mathrm{O} / \mathrm{Ar}$ at the same temperature was used as background.

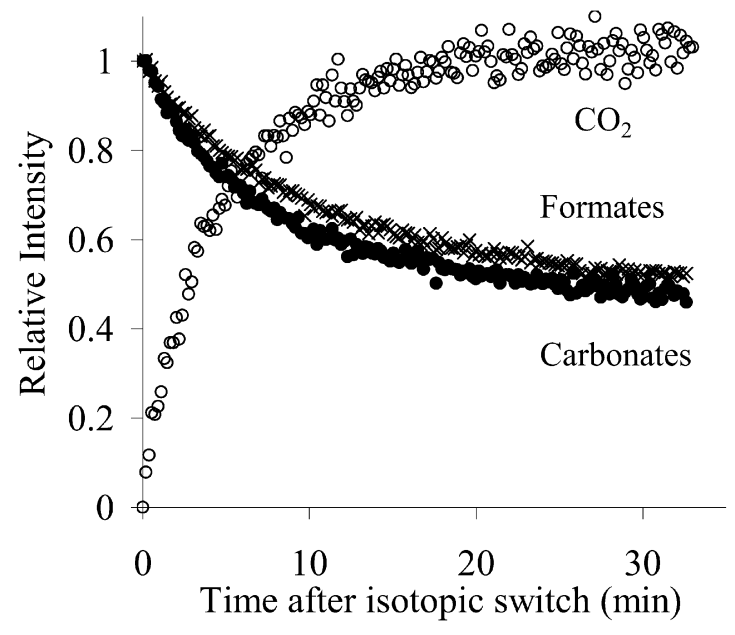

Fig. 5. Relative evolution of the intensity of ${ }^{12} \mathrm{C}$-containing carbonate band $(\bullet)$, ${ }^{12} \mathrm{C}$-containing formate band $(\times)$ and ${ }^{13} \mathrm{CO}_{2}(O)$ signals with time on stream at $428 \mathrm{~K}$ under $2 \%{ }^{13} \mathrm{CO}+7 \% \mathrm{H}_{2} \mathrm{O}$, following steady-state under $2 \%{ }^{12} \mathrm{CO}$ $+7 \% \mathrm{H}_{2} \mathrm{O}$.

example, the formate exchange curves are reported in Fig. 8 using a semilogarithmic plot, which shows that the corresponding lines clearly are not straight.

The sum of two exponential terms was sufficient to obtain a satisfactory fit of the exchange signals for formates and carbonates (not shown). The coefficients of the exponential terms (i.e., pre-exponential factor $A$ and rate constant $k$ ) for the modeling of the formate and carbonate signals are reported in Table 1. Assuming the relevance of a two-species model, the parameters were assigned the letters "s" for slow and " $\mathrm{f}$ " for fast with respect to the slower- and faster-exchanging species related to the lower and higher rate constant, respectively. The Arrhenius plots for the slow and fast formates and carbonates rate constants are shown in Fig. 9. The fast formates were exchanged between 10 (at $493 \mathrm{~K}$ ) and 20 times faster (at $428 \mathrm{~K}$ ) than the slower counterpart. The slower-exchanging formate species exhibited a higher apparent activation energy of decomposition (i.e., $60.8 \mathrm{~kJ} \mathrm{~mol}^{-1}$ ) compared with the faster-exchanging for-

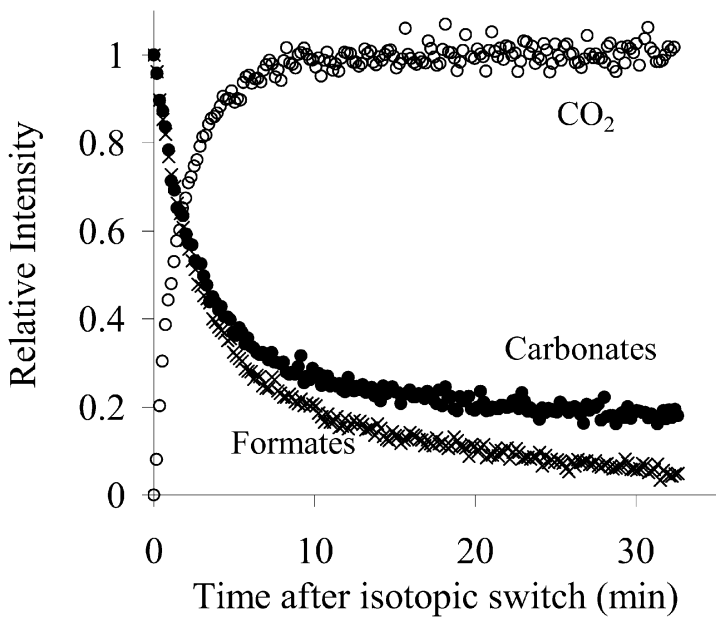

Fig. 6. Relative evolution of the intensity of ${ }^{12} \mathrm{C}$-containing carbonate band ( () , ${ }^{12} \mathrm{C}$-containing formate band $(x)$ and ${ }^{13} \mathrm{CO}_{2}(\mathrm{O})$ signal with time on stream at $493 \mathrm{~K}$ under $2 \%{ }^{13} \mathrm{CO}+7 \% \mathrm{H}_{2} \mathrm{O}$, following steady-state under $2 \%{ }^{12} \mathrm{CO}+$ $7 \% \mathrm{H}_{2} \mathrm{O}$

mates (i.e., $29.9 \mathrm{~kJ} \mathrm{~mol}^{-1}$ ). The pre-exponential factors $A_{s}$ and $A_{f}$ represent the fraction of the slow and fast species (i.e., $\left.A_{s}+A_{f}=1\right)$, respectively. It can be noted that the proportion of fast formate increased at the higher temperatures. Essentially similar observations were made in the case of the carbonates, but both slow and fast carbonates exhibited similar activation energies of decomposition. Again, we see that the apparent activation energy of $40.0 \mathrm{~kJ} \mathrm{~mol}^{-1}$ (see Section 4.1) for the formation of $\mathrm{CO}_{2}$ (determined from the reaction rate values) is significantly different from that of the decomposition of any of the surface species reported above.

\subsection{Quantification of the formate concentration over $0.6 A u C L$}

The quantification of the specific concentration of formate species at the surface of the $0.6 \mathrm{AuCL}$ was determined via a calibration curve, which was obtained from standard samples prepared by incipient wetness impregnation of the ceria-lanthana 


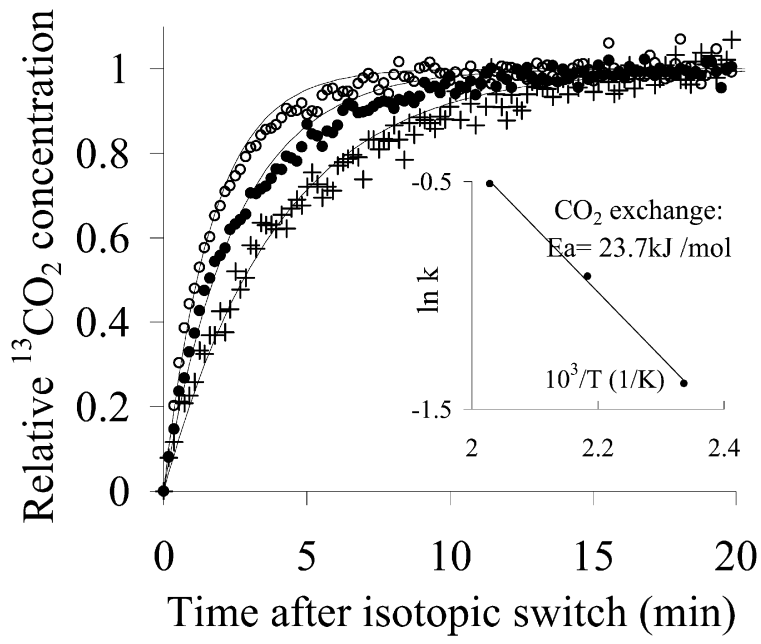

Fig. 7. Relative evolution of the ${ }^{13} \mathrm{CO}_{2}$ signal with time on stream at three different temperatures $428 \mathrm{~K}(+), 458 \mathrm{~K}(\bullet), 493 \mathrm{~K}(\mathrm{O})$ under $2 \%{ }^{13} \mathrm{CO}+7 \%$ $\mathrm{H}_{2} \mathrm{O}$, following steady-state in $2 \%{ }^{12} \mathrm{CO}+7 \% \mathrm{H}_{2} \mathrm{O}$. Insert: Arrhenius plot and corresponding apparent activation energy of the rate constant related to the exchange of $\mathrm{CO}_{2}(\mathrm{~g})$.

Time after isotopic switch ( $\mathrm{min}$ )

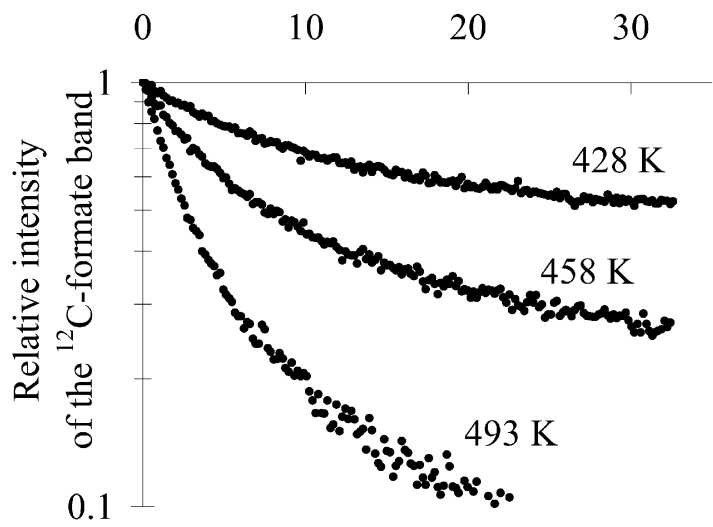

Fig. 8. Semilogarithmic plots of the relative evolution of the intensity of ${ }^{12} \mathrm{C}$-containing formate band with time on stream at different temperatures under $12 \%{ }^{13} \mathrm{CO}+7 \% \mathrm{H}_{2} \mathrm{O}$, following steady-state under $2 \%{ }^{12} \mathrm{CO}+7 \% \mathrm{H}_{2} \mathrm{O}$.

(CL) support with a solution of sodium formate. The standard samples did not contain any Au to prevent the decomposition of the adsorbed formates with time. The spectrum of the standard loaded with $0.125 \mathrm{wt} \%$ formate on CL is shown in Fig. 10a, along with an in situ spectrum obtained under WGS conditions over the $0.6 \mathrm{AuCL}$ at $458 \mathrm{~K}$. The calibration plot was drawn by reporting the area of the $2830 \mathrm{~cm}^{-1}$ peak as a function of the concentration of the standard (Fig. 10b). The values of formate concentration at the three temperatures investigated are reported in Table 1 , in $10^{-6}$ mol per gram of catalyst. These values corresponded to a surface density of about $1.2 \times 10^{-7} \mathrm{~mol} \mathrm{~m}^{-2}$.

\subsection{Comparison of the formate decomposition rate and the rate of $\mathrm{CO}_{2}$ formation}

The relevance of the formate seen by DRIFTS in the formation of $\mathrm{CO}_{2}$ must be evaluated by comparing the molar rate of

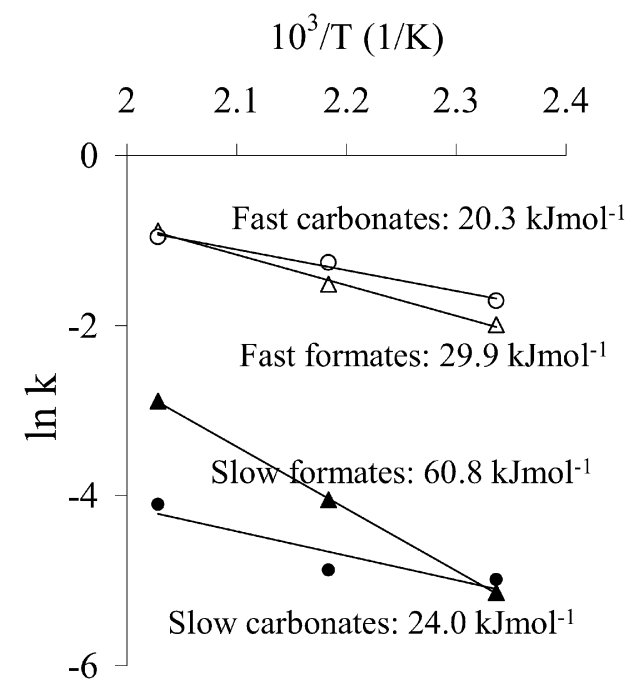

Fig. 9. Arrhenius plots of the rate constant related to the exchange of the fast formates $(\Delta)$, the slow formates $(\boldsymbol{\Delta})$, the fast carbonates $(\bigcirc)$ and the slow carbonates $(\mathbf{)})$. The corresponding apparent activation energies are also reported.

formate decomposition to that of $\mathrm{CO}_{2}$ formation per mass of catalyst. The specific rate of $\mathrm{CO}_{2}$ formation was simply determined from the accurate measurement of the $\mathrm{CO}_{2}$ concentration in the DRIFTS cell exhaust gas by gas-chromatography, the sample weight in the DRIFTS crucible and the flow rate of reactants used. The rate of formate decomposition was calculated as the sum for the fast and slow formates of the corresponding product of the rate constant for exchange and the concentration (Table 1), that is, rate of formate decomposition $=k_{s}$ [slow formates] $+k_{f}$ [fast formates], where [slow formates] $=A_{s}$ [formates] and [fast formates] $=A_{f}$ [formates].

Note that the decomposition rate of the slow formate species was almost negligible compared with that of the fast formates. The semilogarithmic plot reporting the rates in Fig. 11 shows that the rate of formate decomposition was more than an order of magnitude smaller (ca. 60-fold) than the rate of $\mathrm{CO}_{2}$ formation.

\section{Discussion}

\subsection{Ceria oxidation state and nature of the surface species}

The combination of the in situ DRIFTS and the SSITKA technique facilitated the assignment of the bands observed under WGS conditions over the $0.6 \% \mathrm{Au} / \mathrm{Ce}(\mathrm{La}) \mathrm{O}_{2}$ catalyst. In particular, the band observed here at $2132 \mathrm{~cm}^{-1}$ (located at $2125 \mathrm{~cm}^{-1}$ before baseline correction) appears to be solely due to the normally forbidden electronic transition of reduced ceria [39] and not to any $\mathrm{CO}$ (ads), because no band shift was observed on $\mathrm{CO}(\mathrm{g})$ isotopic exchange (Fig. 3). Note that a band at ca. $2130-2140 \mathrm{~cm}^{-1}$ was observed on the same sample from 120 to $373 \mathrm{~K}$ and assigned to $\mathrm{CO}$ adsorbed on $\mathrm{Au}_{\mathrm{n}}^{+}$clusters in work reported by some of us elsewhere [10]. However, the experimental conditions used here are markedly different, that is, significantly higher temperatures (428-493 K) and the presence of $7 \% \mathrm{H}_{2} \mathrm{O}$. The bonding of $\mathrm{CO}$ on $\mathrm{Au}$ is typically weak, which explains the fact that no carbonyl bands could be detected in the 


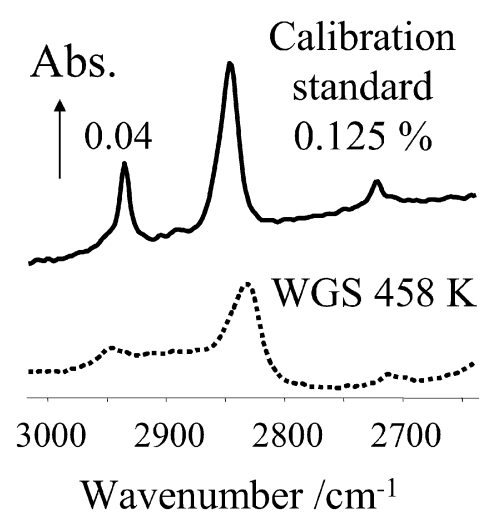

(a)

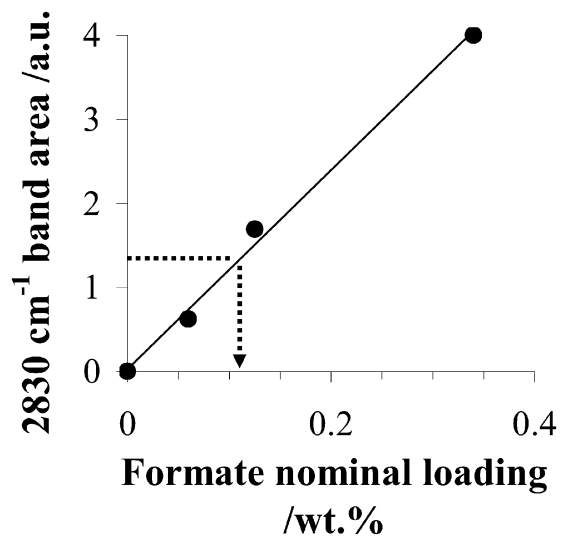

(b)

Fig. 10. (a) Upper spectrum: DRIFT spectrum observed over a $\mathrm{Au}$-free $\mathrm{Ce}(\mathrm{La}) \mathrm{O}_{2}$ material at $373 \mathrm{~K}$ in $\mathrm{Ar}$ impregnated with $0.125 \mathrm{wt} \%$ of formate deposited from sodium formate. Lower spectrum: in situ DRIFT spectrum observed over the $0.6 \mathrm{AuCL}$ under $2 \%{ }^{13} \mathrm{CO}+7 \% \mathrm{H}_{2} \mathrm{O}$ in Ar. $T=458 \mathrm{~K}$. (b) Calibration plot relating the formate $\mathrm{CH}$ stretching band area of the $\mathrm{Ce}(\mathrm{La}) \mathrm{O}_{2}$ sample impregnated with various loading of sodium formates. The dotted line is associated with the in situ spectrum shown in (a).

Table 1

Parameters representing the two-term exponential model of the formate and carbonate exchange curves

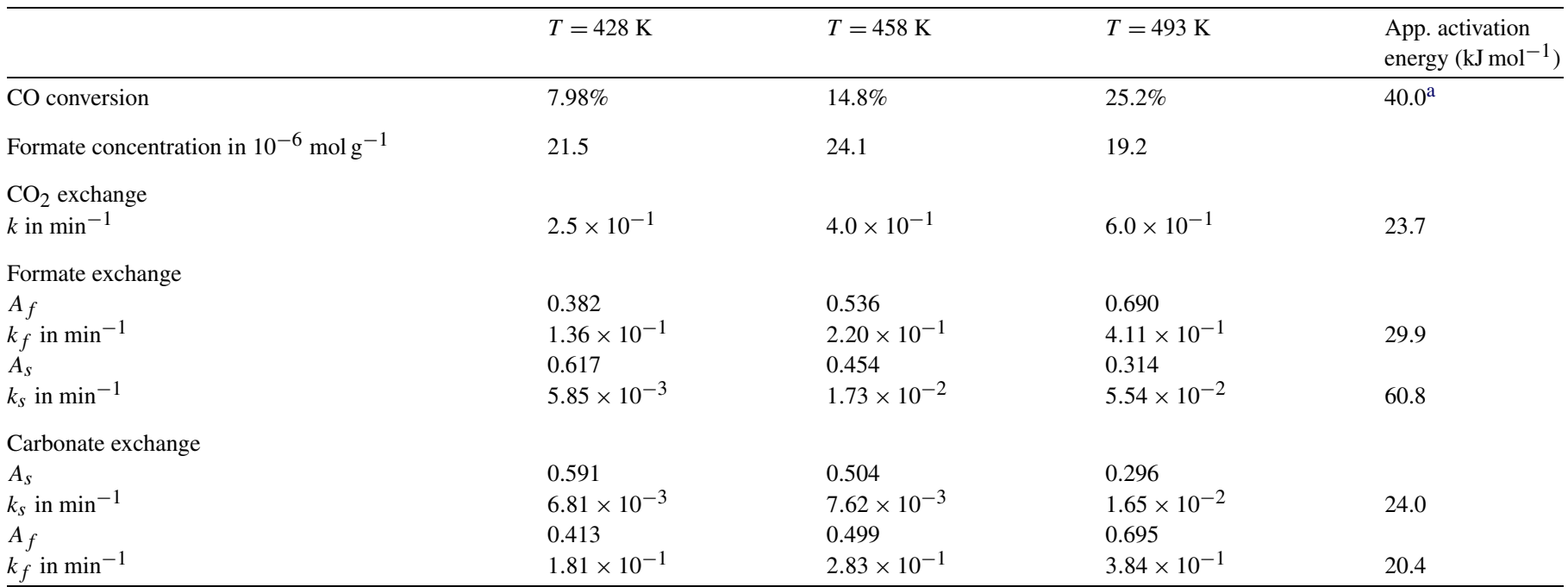

Signal form $=A_{f} e^{-k_{f} x t}+A_{s} e^{-k_{s} x t}$. The $\mathrm{CO}_{2}$ exchange plot was fitted with a single exponential function.

a Determined from data measured in differential conditions, i.e. conversion $<15 \%$ (Fig. 1).

range of higher temperatures used here. The corresponding low surface coverage of $\mathrm{Au}$ by $\mathrm{CO}$ suggests that $\mathrm{CO}$ adsorption may be the rate-determining step of the WGS reaction. As a matter of fact, a $\mathrm{CO}$ reaction order of 1 is often observed for Au-based WGS catalysts [40]. This is in contrast with $\mathrm{Pt} / \mathrm{CeO}_{2}$ catalysts, for which a strong carbonyl band is observed even around $500 \mathrm{~K}$ [30] and the CO reaction order is typically $0[5,15]$.

The bands associated with formate and carbonate species were broad and ill-defined (Figs. 2-4), as would be expected over a high-surface area nanocrystalline sample. Nonetheless, our DRIFTS-SSITKA experiments were able to identify a nonuniform reactivity of the surface formates and carbonates, because neither the formate (Fig. 8) nor the carbonate (not shown) exchange curve fit a simple exponential decay. Note that first-order exchanges, which are associated with single exponential laws, have been observed for formates under similar reaction conditions over $\mathrm{Pt} / \mathrm{CeO}_{2}$ [29] and $\mathrm{Pt} / \mathrm{ZrO}_{2}$ [41]. The fact that a sum of two exponential terms could represent the exchange of formates and carbonates suggests that two main types of reactivity were present. This observation is crucial, because formate and carbonate species in the WGS reaction are usually considered to exhibit the same reactivity. Davis et al. [27] recently reported two different types of formates over $\mathrm{Pt} / \mathrm{Ce}(\mathrm{Zr}) \mathrm{O}_{2}$ materials relating to Ce-rich or $\mathrm{Zr}$-rich regions, but it was not clear whether these species displayed the same reactivity.

As mentioned by one of the referees, an apparent twofold increase in formate reactivity also could have arisen from a variation of the molar absorption coefficient (absorptivity) with surface coverage. But we believe that this was not the case here, for the following reasons. First, the proportion of slow formate species varied quite significantly (between 60\% and 


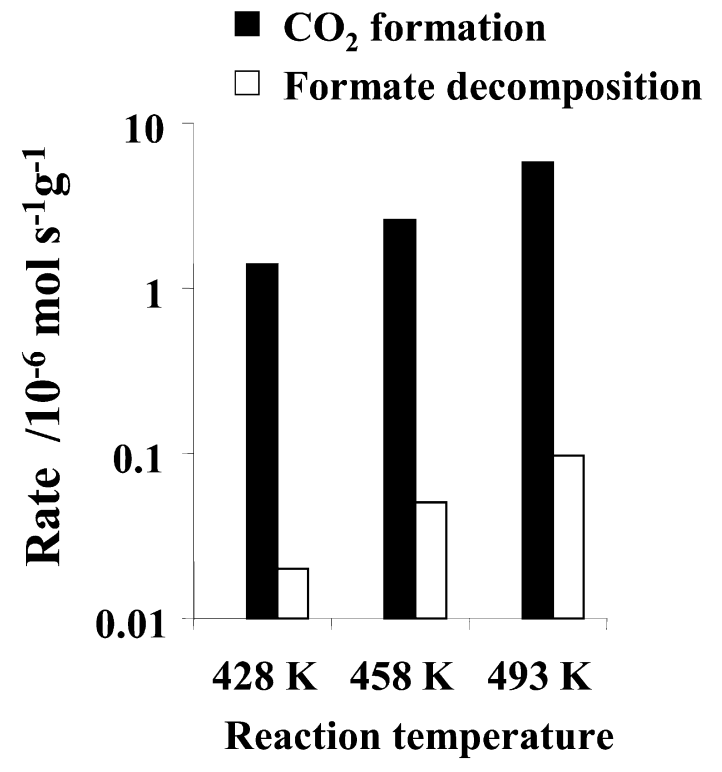

Fig. 11. Rate of $\mathrm{CO}_{2}$ production and rate of formate decomposition over the $0.6 \mathrm{AuCL}$ at three different temperatures under $2 \%{ }^{12} \mathrm{CO}+7 \% \mathrm{H}_{2} \mathrm{O}$.

$30 \%$ ) over the temperature range investigated, whereas the total formate concentration remained essentially constant (Table 1). A change of absorptivity with coverage cannot explain these observations. In other words, a variation of absorptivity would have to be considered only if the proportion of slow formates was the same at all temperatures, which could then be possibly explained by a coverage-dependent absorptivity. Second, the experiments were carried at constant coverage, with only the isotopic nature of the adsorbates varied. Third, in the present case, we can assume that the distance between formates was sufficiently large so as to limit any lateral interactions. This is supported by the fact that the number of surface formates is $<1 \%$ of the number of surface oxide ions (see Table 2; multiply the values in the last and antepenultimate lines). Fourth, the decay of the formate signal over similar catalysts during isotopic exchange [29,41] or during an Ar purge (data to be published) showed that a perfect single first-order decay was obtained, demonstrating that the absorptivity of formates was not coverage-dependent in these cases. Finally, the calibration plot given in Fig. 10b clearly shows that the DRIFTS signal of formates was proportional to formate surface concentration. In view of all of these arguments, it is unlikely that the absorptivity of formates was coverage-dependent in the present case.

\subsection{Origin of the nonuniform reactivity of formates and carbonates}

The twofold or greater increase in reactivity of surface intermediates could have various origins, which we did not explore in the present study. First, the sites of different reactivities could be related to $\mathrm{Ce}$ or La cations, or even to surface patches of the segregated oxides. The fact that the ratio of fast to slow species varied widely over the temperature range used (see the values of $A_{f}$ and $A_{s}$ in Table 1) while the fraction of La close to the surface (ca. 20 at $\%$ ) was expected to remain approximately
Table 2

Density of $\mathrm{CO}_{2}$ precursors as measured by SSITKA over 0.6AuCL $\left(161 \mathrm{~m}^{2} \mathrm{~g}^{-1}\right)$

\begin{tabular}{llll}
\hline & $T=428 \mathrm{~K}$ & $T=458 \mathrm{~K}$ & $T=493 \mathrm{~K}$ \\
\hline$N_{\mathrm{CO}_{2}}=$ number of $\mathrm{CO}_{2}$ & 3.67 & 4.00 & 5.49 \\
precursors $\left(10^{-4} \mathrm{~mol} \mathrm{~g}^{-1}\right)$ & & & \\
Surface $\mathrm{O} / N_{\mathrm{CO}_{2}}$ & 9.9 & 9.1 & 6.6 \\
$N_{\mathrm{CO}_{2}} / \mathrm{Au}$ & 154 & 168 & 231 \\
$N_{\mathrm{CO}_{2}}$ /formate & 17 & 18 & 29 \\
\hline
\end{tabular}

Au was assumed to be $100 \%$ dispersed, leading to a surface O/Au ratio of ca. 1500. $\mathrm{CeO}_{2}$ has a cubic cell with four oxygen atoms on each face, the surface area of which is ca. $2.92 \times 10^{-19} \mathrm{~m}^{2}$. The theoretical number of moles of oxygen atoms, or oxide ions, per $\mathrm{m}^{2}$ of catalyst surface is $22.7 \times 10^{-6}$.

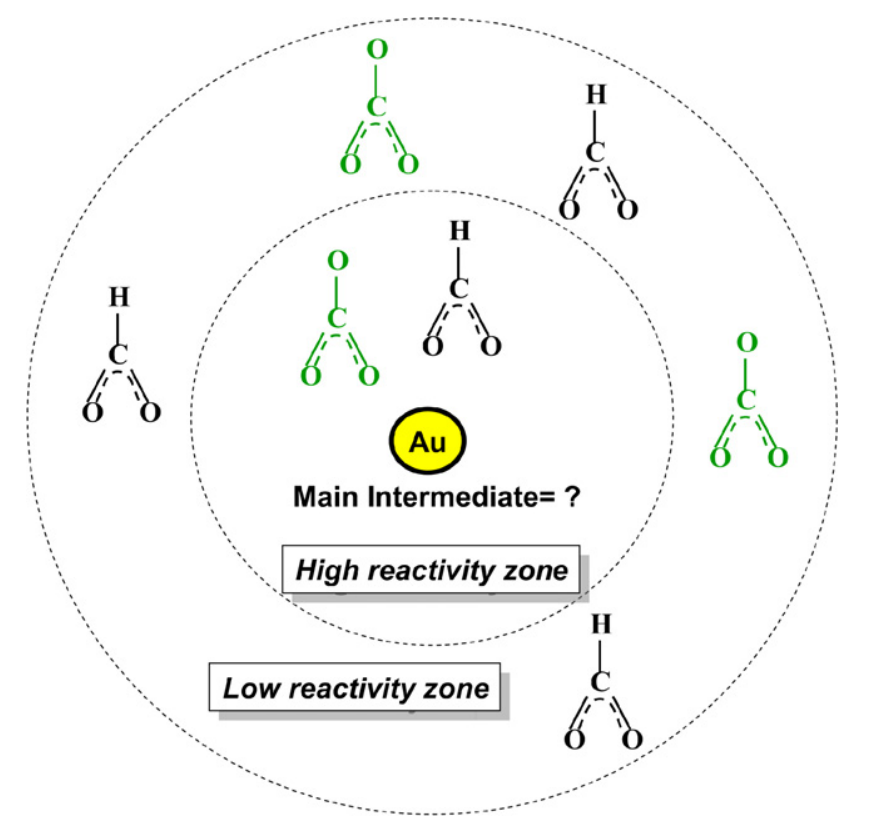

Fig. 12. Schematic representation of the species populating the surface of the $0.6 \mathrm{AuCL}$ catalyst during the water-gas shift reaction. It is suggested that the surface species close to the Au centers are the most reactive, while those further away are essentially spectators. The origin of the difference of reactivity is unclear.

constant can be explained by a variable extent of adsorbate spillover with temperature [42]. Second, the promoting effect of the Au could spread to an increasing distance with higher temperatures. This could be due to an enhanced "normal-support activation" electronic effect [43], to an increased extent of the "active" reduced ceria area around the Au particles as proposed for $\mathrm{Pt} / \mathrm{CeO}_{2}$ [25,44], or to an increased capture zone of slowly diffusing surface species, as proposed on $\mathrm{Au} / \mathrm{CeO}_{2}$ [28]. Third, and somewhat similar to the aforementioned point, the mobility of surface Au atoms should increase with temperature, explaining the larger fraction of reactive intermediates. A scheme summarizing these various possibilities is given in Fig. 12.

It is interesting to note that the 0.6AuCL catalyst used here has the characteristic $\mathrm{CO}$ temperature reduction profile reported before for these $\mathrm{Au}-\mathrm{O}-\mathrm{Ce}$ surfaces (devoid of gold particles before reaction) [7], with two resolved surface oxygen reduction peaks, noted as $\mathrm{Os}_{1}$ and $\mathrm{Os}_{2}$. The $\mathrm{Os}_{1}$ species was reduced below $473 \mathrm{~K}$ and thus would be expected to be partly 


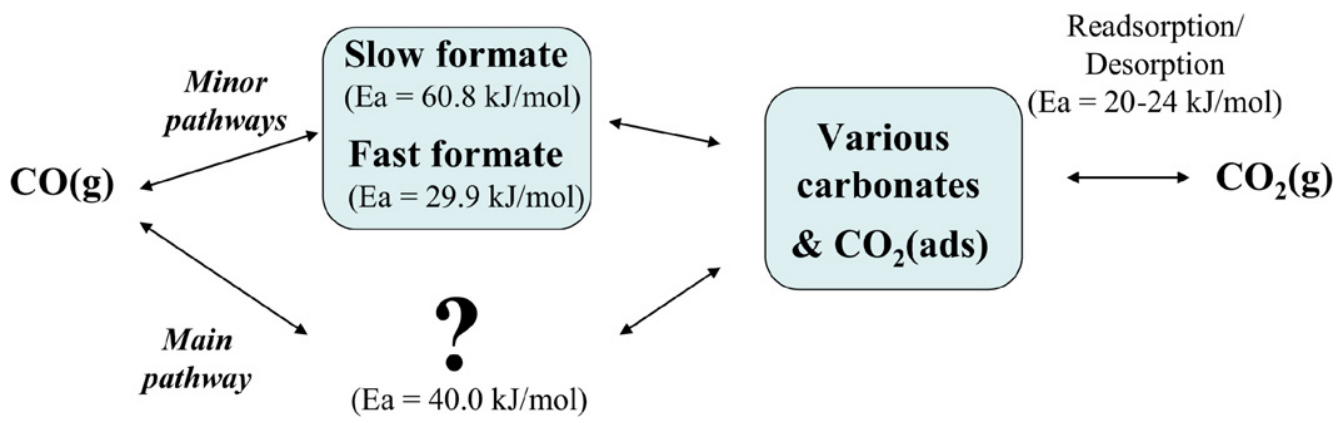

Fig. 13. Suggested reaction scheme taking place over the 0.6AuCL catalysts during the water-gas shift reaction. The intermediate $\mathrm{X}$ could possibly be a species formed by reaction between $\mathrm{CO}$ adsorbed on Au and an oxide ion, as in a redox mechanism, or an adduct species, possibly a formate not resolved on the DRIFT spectrum.

reduced under our reaction conditions $\left(2 \% \mathrm{CO}+7 \% \mathrm{H}_{2} \mathrm{O}\right)$, in agreement with the fact that ceria was partly reduced during our investigation. Following an initial report by Löffler et al. [9], ceria surface reduction and the formation of $\mathrm{Ce}(\mathrm{III})$ carbonates has a widely proposed cause of catalyst deactivation $[11,29,45,46]$ during the WGS reaction over ceria-based catalysts. Thus, it is possible that the most stable adsorbate (i.e., so-called "slow" species) would be that adsorbed on Os 1 sites. This stable formate would then become more reactive as the temperature increases and water activation and O-diffusion facilitate the reoxidation of $\mathrm{Os}_{1}$ sites. More work would be required to probe the various possibilities proposed in this section and determine the true origin of the nonuniform reactivity observed.

It must be noted that the level of reduction of ceria under our less-reducing conditions must be limited, although it is observable. Mogensen et al. [47] have reported equilibrium plots describing the extent of ceria reduction as a function of the partial pressure of $\mathrm{O}_{2}$. Based on these plots, we estimate that bulk $\mathrm{CeO}_{2}$ should be reduced to $\mathrm{CeO}_{1.9}$ under our conditions, for which the corresponding theoretical $\mathrm{O}_{2}$ pressure was ca. $10^{-42} \mathrm{~atm}$. WGS catalyst deactivation due to Ce(III) carbonate formation is established in the literature [11,20]. As long as $\mathrm{CeO}_{2}$ is completely oxidized, it does not adsorb $\mathrm{CO}_{2}$ [48]. The presence of $\mathrm{Ce}^{3+}$ in catalysts after the WGS reaction was identified by XRD [11] and by XPS [49] even though the $\mathrm{Ce}^{3+}$ concentration may be overestimated by XPS [50-52]. The oxygen defect concentration increases with addition of trivalent La. Near the surface, the La (19.1 at\%) content was more than twofold that in the bulk of ceria; the same is true for the corresponding concentration of oxygen vacancies. In the presence of $\mathrm{Au}$, the surface reduction of ceria is much easier as evidenced by TPR data [18]. All surface oxygen of ceria was reduced below $473 \mathrm{~K}$. Reactivation of ceria requires heating in air at $T>350^{\circ} \mathrm{C}$ to decompose the carbonate [11].

\section{3. $\mathrm{CO}_{2}$ precursors and readsorption effects}

The number of reaction product precursors of $\mathrm{CO}_{2}$ measured by the SSITKA method [53-55] over the 0.6AuCL are given in Table 2. It should be stressed that these numbers are by no means to be taken as the number of active sites, because product readsorption can occur, leading to active site number overestimation. The number of $\mathrm{CO}_{2}$ precursors increased with temperature and was always two orders of magnitude higher than the number of surface Au atoms (assuming 100\% dispersion). Such a large number of precursors and the well-known facts that ceria is a strongly basic oxide and $\mathrm{CO}_{2}$ is an acidic molecule raise the concern of extensive $\mathrm{CO}_{2}$ readsorption during the course of the reaction.

Typical $\mathrm{CO}_{2}$ desorption rate constant values over similar basic materials measured during ${ }^{12} \mathrm{CO}_{2}-{ }^{13} \mathrm{CO}_{2}$ exchanges (with no other reactive gas present) have been reported $[56,57]$ and were of a similar order of magnitude to that of the exchange rate constant $\mathrm{k}$ determined here, that is, $0.1-1 \mathrm{~min}^{-1}$ (Table 1). The apparent activation energy for $\mathrm{CO}_{2}$ formation (determined from the reaction rate values) was equal to $40.0 \mathrm{~kJ} \mathrm{~mol}^{-1}$, significantly greater than that of the exchange of $\mathrm{CO}_{2}$ (i.e., $23.7 \mathrm{~kJ} \mathrm{~mol}^{-1}$ ). The apparent activation energy of $\mathrm{CO}_{2}$ exchange $\left(23.7 \mathrm{~kJ} \mathrm{~mol}^{-1}\right)$ was actually similar to that of carbonate exchange (slow carbonate, $24.0 \mathrm{~kJ} \mathrm{~mol}^{-1}$; fast carbonates, $20.4 \mathrm{~kJ} \mathrm{~mol}^{-1}$ ). These observations strongly support the hypothesis that a significant fraction of $\mathrm{CO}_{2}$ readsorbed on the catalyst as carbonates, and that the $\mathrm{CO}_{2}(\mathrm{~g})$ exchange was dominated by this "unreactive" adsorption/desorption phenomenon and masked the process of conversion of $\mathrm{CO}$ to $\mathrm{CO}_{2}$. A scheme summarizing the different events occurring during the reaction is given in Fig. 13.

Although fast $\mathrm{CO}_{2}$ readsorption/desorption occurred, involving a greater proportion of the surface at higher temperatures, it is still worth pointing out that a significant fraction of carbonates did not exchange over durations much greater than the time needed to complete $\mathrm{CO}_{2}$ exchange, stressing the complex nature of the sample reactivity. A full analysis of the SSITKA data [53] gathered over such samples that exhibit a large concentration of adsorption sites and sites with varying reactivity is too complex to yield any unambiguous conclusions and thus was not attempted. Note that a more detailed SSITKA analysis was possible in the case of a low-basicity $\mathrm{Pt} / \mathrm{ZrO}_{2}$ material, for which the amount of $\mathrm{CO}_{2}$ precursors was found to be even less than the number of surface Pt atoms [41]. In the present case, the number of $\mathrm{CO}_{2}$ precursors was more than an order of magnitude higher than that of surface formates (Table 2). Because $\mathrm{CO}_{2}$ readsorption occurred, such a high ratio 
cannot serve as evidence to rule in or rule out formates as surface intermediates.

\subsection{Role of the formates detected by DRIFTS in $\mathrm{CO}_{2}$ production}

Whereas $\mathrm{CO}_{2}$ readsorption hindered the analysis of the $\mathrm{CO}_{2}$ exchange signals, the observed exchange rate of formates and the corresponding steady-state surface coverage allowed us to calculate the specific rate of formate decomposition, which turned out to be an order of magnitude lower than the rate of $\mathrm{CO}_{2}$ formation (Fig. 11). These data unambiguously prove that the formats detected by DRIFTS are not main reaction intermediates in the formation of $\mathrm{CO}_{2}$ during the WGS over this $0.6 \mathrm{AuCL}$ catalyst under our reaction conditions. These formates (slow + fast) should be labeled "minor reaction intermediates," not "spectators," because they still led to some reaction product, although at an almost negligible rate compared with that of the main, yet unknown route. As indicated by Behm et al. [28], these formates could diffuse and react at the Ausupport interface, being a kind of "buffer" species storing CO at the surface of the sample. Nonetheless, it should be stressed that this does not prove by any means that the main reactive intermediate leading to the formation of $\mathrm{CO}_{2}$ is a formate. The main WGS pathway remains unclear (Fig. 13), for example, redox route or interface adduct (not excluding formates) of a concentration too low to be observable by in situ DRIFTS.

\section{Conclusion}

The following conclusions can be drawn from the results of our in situ DRIFTS-SSITKA study of the WGS reaction over a $0.6 \% \mathrm{Au} / \mathrm{Ce}(\mathrm{La}) \mathrm{O}_{2}$ catalyst between 428 and $493 \mathrm{~K}$ :

1. The importance of fully quantifying not only the rate of exchange, but also the absolute amounts of surface species has been established, showing that otherwise very misleading conclusions about possible reaction intermediates can be drawn.

2. The specific rate of $\mathrm{CO}_{2}$ formation was ca. 60 times higher than the rate of formate decomposition (fast + slow species) decomposition, showing that the formates detected by DRIFTS are not important in the main reaction pathway.

3. Nonuniform reactivity of the surface formates and carbonates was observed, which could be fitted to a bimodal distribution relating to slow- and fast-exchanging species.

4. A significant readsorption of the reaction product $\mathrm{CO}_{2}$ occurred, which disguised the exchange curves and the number of precursors as determined by the SSITKA method.

\section{Acknowledgments}

This work was partly supported by the EPSRC, under the CARMAC project and the European Social Funds (D.R.). W.D. and M.F.-S. acknowledge the support of this work by the U.S. National Science Foundation, NIRT Grant \#0304515; and by the U.S. Department of Energy, Basic Energy Sciences, Hydrogen Fuel Initiative Grant \#DE-FG02-05ER15730.

\section{References}

[1] T. Tabakova, F. Boccuzzi, M. Manzoli, J.W. Sobczak, V. Idakiev, D. Andreeva, Appl. Catal. B 49 (2004) 73.

[2] T. Tabakova, F. Boccuzzi, M. Manzoli, J.W. Sobczak, V. Idakiev, D. Andreeva, Appl. Catal. A 298 (2006) 127.

[3] T. Shido, Y. Iwasawa, J. Catal. 136 (1992) 493.

[4] G. Jacobs, L. Williams, U. Graham, D. Sparks, B.H. Davis, J. Phys. Chem. B 107 (2003) 10398.

[5] G. Jacobs, L. Williams, U. Graham, D. Sparks, G. Thomas, B.H. Davis, Appl. Catal. A 252 (2003) 107.

[6] G. Jacobs, E. Chenu, P. M Patterson, L. Williams, D. Sparks, G. Thomas, B.H. Davis, Appl. Catal. A 258 (2004) 203.

[7] Q. Fu, H. Saltsburg, M. Flytzani-Stephanopoulos, Science 301 (2003) 935.

[8] A. Goguet, D. Tibiletti, F.C. Meunier, J.P. Breen, R. Burch, J. Phys. Chem. B 108 (2004) 20240.

[9] J.M. Zalc, V. Sokolvskii, D.G. Löffler, J. Catal. 206 (2002) 169.

[10] M. Manzoli, F. Boccuzzi, A. Chiorino, F. Vindigni, W. Deng, M. FlytzaniStephanopoulos, J. Catal. 245 (2007) 306.

[11] W. Deng, M. Flytzani-Stephanopoulos, Angew. Chem. Int. Ed. 45 (2006) 2285.

[12] C.M.Y. Yeung, F. Meunier, R. Burch, D. Thompsett, S.C. Tsang, J. Phys. Chem. B 110 (2006) 8540.

[13] Y. Amenomiya, Appl. Spectrosc. 32 (1978) 484.

[14] Y. Li, Q. Fu, M. Flytzani-Stephanopoulos, Appl. Catal. B 27 (2000) 179.

[15] T. Bunluesin, R.J. Gorte, G.W. Graham, Appl. Catal. B 15 (1998) 107.

[16] S. Hilaire, X. Wang, T. Luo, R.J. Gorte, J. Wagner, Appl. Catal. A 215 (2001) 271

[17] X. Wang, R.J. Gorte, Catal. Lett. 73 (2001) 15.

[18] Q. Fu, A. Weber, M. Flytzani-Stephanopoulos, Catal. Lett. 77 (2001) 87.

[19] T. Luo, R.J. Gorte, Catal. Lett. 85 (2003) 139.

[20] X. Wang, R.J. Gorte, J.P. Wagner, J. Catal. 212 (2002) 225.

[21] R. Burch, Phys. Chem. Chem. Phys. 8 (2006) 5483.

[22] T. Shido, Y. Iwasawa, J. Catal. 141 (1993) 71.

[23] G. Jacobs, S. Ricote, U.M. Graham, P.M. Patterson, B.H. Davis, Catal. Today 106 (2005) 259.

[24] G. Jacobs, B. Davis, Appl. Catal. A 285 (2005) 43.

[25] G. Jacobs, U.M. Graham, E. Chenu, P.M. Patterson, A. Dozier, B.H. Davis, J. Catal. 229 (2005) 499.

[26] G. Jacobs, B.H. Davis, Appl. Catal. A 284 (2005) 31; G. Jacobs, B.H. Davis, Appl. Catal. A 284 (2005) 499

[27] S. Ricote, G. Jacobs, M. Milling, Y. Ji, P.M. Patterson, B.H. Davis, Appl. Catal. A 303 (2006) 35.

[28] R. Leppelt, B. Schumacher, V. Plzak, M. Kinne, R.J. Behm, J. Catal. 244 (2006) 137.

[29] F.C. Meunier, D. Tibiletti, A. Goguet, S. Shekhtman, C. Hardacre, R. Burch, Catal. Today (2007), doi:10.1016/j.cattod.2006.10.003, in press.

[30] D. Tibiletti, A. Goguet, F.C. Meunier, J.P. Breen, R. Burch, Chem. Commun. (2004) 1636.

[31] M.W. Balakos, S.S.C. Chuang, G. Srivinas, J. Catal. 140 (1993) 281.

[32] R.W. Stevens, S.S.C. Chuang, J. Phys. Chem. B 108 (2004) 696.

[33] J.M. Olinger, P.R. Griffiths, Anal. Chem. 60 (1988) 2427.

[34] C. Binet, M. Daturi, J.C. Lavalley, Catal. Today 50 (1999) 207.

[35] M. Daturi, C. Binet, J.C. Lavalley, G. Blanchard, Surf. Interface Anal. 30 (2000) 273.

[36] C. Li, Y. Sakata, T. Arai, K. Domen, K.-I. Maruya, T. Onishi, J. Chem. Soc. Faraday Trans. 85 (1989) 1451.

[37] P. Bazin, O. Saur, J.C. Lavalley, M. Daturi, G. Blanchard, Phys. Chem. Chem. Phys. 7 (2005) 187.

[38] G. Busca, J. Lamotte, J.C. Lavalley, V. Lorenzelli, J. Am. Chem. Soc. 109 (1987) 5197.

[39] C. Binet, A. Badri, J.C. Lavalley, J. Phys. Chem. 98 (1994) 6392.

[40] G. Jacobs, P.M. Patterson, L. Williams, E. Chenu, D. Sparks, G. Thomas, B.H. Davis, Appl. Catal. A 285 (2005) 43. 
[41] D. Tibiletti, F.C. Meunier, A. Goguet, D. Reid, R. Burch, M. Boaro, M. Vicario, A. Trovarelli, J. Catal. 244 (2006) 183.

[42] M. Daturi, O. Marie, personal communication, Caen, 2006.

[43] J.C. Frost, Nature 334 (1988) 577.

[44] A. Goguet, F.C. Meunier, J.P. Breen, R. Burch, M.I. Petch, A. Faur Ghenciu, J. Catal. 226 (2004) 382.

[45] D. Tibiletti, A. Goguet, D. Reid, F.C. Meunier, R. Burch, Catal. Today 113 (2006) 94.

[46] Q. Fu, W. Deng, H. Saltsburg, M. Flytzani-Stephanopoulos, Appl. Catal. B 56 (2005) 57.

[47] M. Mogensen, N.M. Sammes, G.A. Tompsett, Solid State Ionics 129 (2000) 63.

[48] S. Sharma, S. Hilaire, J.M. Vohs, R.J. Gorte, H.-W. Jen, J. Catal. 190 (2000) 199.
[49] Q. Fu, Ph.D. thesis, Department of Chemical and Biological Engineering, Tufts University, 2004.

[50] E. Paparazzo, G.M. Ingo, N. Zacchetti, J. Vac. Sci. Technol. A 9 (3) (1991) 1416.

[51] M.V. Rama Rao, T. Shripathi, J. Electron. Spectrosc. Relat. Phenom. 87 (1997) 121.

[52] F. Zhang, P. Wang, J. Koberstein, S. Khalid, S.-W. Chan, Surf. Sci. 563 (2004) 74.

[53] S.L. Shannon, J.G. Goodwin, Chem. Rev. 95 (1995) 677.

[54] C.N. Costa, A.M. Efstathiou, J. Phys. Chem. B 108 (2004) 2620.

[55] Y. Schuurman, C. Mirodatos, Appl. Catal. A 151 (1997) 305.

[56] M. Xu, E. Iglesia, J. Phys. Chem. B 102 (1998) 961.

[57] F.C. Meunier, D. Tibiletti, A. Goguet, D. Reid, R. Burch, Appl. Catal. A 289 (2005) 104. 